\title{
INCREASING ABILITY TO SOLVE MATH WORD PROBLEM THROUGH LOGAN AVENUE PROBLEM SOLVING (LAPS-HEURISTIK) LEARNING
}

\section{Umi Rofi'atul Mahmudah, Retno Winarni, Tri Budiharto}

Universitas Sebelas Maret umirofiatul907@gmail.com

\section{Article History}

accepted 09/07/2018

approved 01/08/2018

published 17/09/2018

\section{Keywords}

ability, math word problem, LAPS-Heuristic Learning

\begin{abstract}
The purpose of this research is to improve the students' ability to solve math word problem in fifth grade of State Elementary School of Tegalsari No.60 Surakarta in the academic year 2017/2018 through Logan Avenue Problem Solving (LAPSHeuristic) learning. The data collecting techniques were indepth interviews, observations, tests, and documentation. The data validating technique were content validity, technique triangulation, and source triangulation. Data analyzing were descriptive comparative analysis and interactive analysis. The results of this class action research showed the achievement of the ability to solve math word problem at fifth-grade students of Tegalsari State Elementary School No.60 Surakarta academic year 2017/2018. The classical completeness of students' score to solve math word problem has increased, from $33,33 \%$ in pretest to $57,14 \%$ in cycle $I$, and $85,71 \%$ in cycle II. The conclusion of this research is the use of LAPSHeuristic learning can improve the students' ability to solve math word problem in fifth-grade of State Elementary School of Tegalsari No.60 Surakarta academic year 2017/2018.
\end{abstract}

Social, Humanities, and Education Studies (SHEs): Conference Series https://jurnal.uns.ac.id/shes
p-ISSN 2620-9284

e-ISSN 2620-9292 


\section{PENDAHULUAN}

Matematika merupakan salah satu mata pelajaran yang mendukung kehidupan manusia di bidang pendidikan. Matematika diperlukan untuk memenuhi kebutuhan praktis dan membantu memecahkan masalah dalam kehidupan sehari-hari. Matematika bertujuan untuk membantu siswa memiliki kemampuan. Kemampuan yang dimaksud antara lain: (1) memahami konsep matematika, (2) memecahkan masalah, (3) mengkomunikasikan gagasan dengan simbol, (4) menggunakan penalaran, dan (5) memiliki sikap menghargai kegunaan matematika dalam kehidupan (Shadiq, 2014).

Kemampuan dapat dikatakan juga sebagai daya, kecakapan, kapasitas, atau potensi yang dimiliki seseorang. Sunarto dan Hartono (2008) menjelaskan bahwa kemampuan merupakan daya untuk melakukan tindakan sebagai hasil dari pembawaan dan latihan yang mendukung seseorang menyelesaikan tugasnya. Seseorang dapat melakukan sesuatu atau menyelesaikan suatu tugas, karena adanya kemampuan yang dimiliki dalam dirinya. Kemampuan tersebut akan semakin baik apabila terus digali melalui beberapa tindakan, seperti kegiatan memecahkan masalah.

Kegiatan memecahkan masalah yang dialami siswa sekolah dasar khususnya kelas $\mathrm{V}$ adalah kegiatan memecahkan masalah dalam soal cerita matematika. Soal cerita matematika adalah soal matematika yang dinarasikan dalam serangkaian kalimat. Serangkaian kalimat tersebut membentuk suatu cerita pendek yang berkaitan dengan konsep materi pembelajaran dan kehidupan nyata siswa. Hal tersebut senada dengan pendapat Sweden, Sandra, dan Japa (dalam Winarni dan Harmini, 2011) yang mengemukakan bahwa soal cerita adalah soal yang diungkapkan dalam bentuk cerita, diambil dari pengalaman siswa, dan berkaitan dengan konsep materi pembelajaran matematika.

Bagi siswa sekolah dasar, tidaklah mudah untuk menyelesaikan soal cerita matematika. Perlu adanya kemampuan khusus yang harus dimiliki seorang siswa. Laily (2014) menyatakan bahwa kemampuan menyelesaikan soal cerita matematika adalah kesanggupan seseorang untuk memecahkan masalah berupa soal matematika yang disajikan dalam bentuk cerita. Berdasarkan temuan di lapangan, kemampuan menyelesaikan soal cerita matematika siswa kelas V SD Negeri Tegalsari No.60 Surakarta tergolong rendah.

Berdasarkan hasil wawancara dengan guru dan siswa kelas $\mathrm{V}$, diperoleh informasi adanya permasalahan pada mata pelajaran matematika pokok bahasan menyelesaikan soal cerita. Siswa merasa kesulitan untuk mengubah soal matematika ke dalam bentuk kalimat matematika. Banyak siswa yang mampu menghitung matematika, namun apabila dituliskan dalam bentuk soal cerita, mereka merasa bingung dan kesulitan.

Berdasarkan hasil observasi terhadap kinerja guru dan aktivitas siswa, diperoleh informasi bahwa guru belum mengoptimalkan penggunaan model pembelajaran inovatif dalam pembelajarannya. Guru memulai pembelajaran dengan memberikan contoh soal, meminta siswa mengerjakan soal tersebut, dan membahasnya. Guru belum membiasakan kepada siswa cara menyelesaikan soal cerita menggunakan langkah-langkah menyelesaikan soal cerita yang benar dan runtut. Hal tersebut mengakibatkan siswa cenderung langsung menuliskan jawaban tanpa menuliskan prosedur penyelesaian yang lengkap. Padahal, siswa yang mampu menyelesaikan soal cerita dengan prosedur penyelesaian yang lengkap dapat dikatakan sebagai siswa yang memiliki pemahaman dan kemampuan tinggi. Oleh karena itu, kondisi tersebut memperlihatkan bahwa kemampuan siswa dalam menyelesaikan soal cerita matematika masih rendah.

Hasil uji pratindakan mengenai kemampuan menyelesaikan soal cerita matematika menunjukkan bahwa sebagian besar siswa masih mendapatkan nilai di bawah kriteria ketuntasan minimal (KKM) yang ditentukan SD, yaitu sebesar 75. 
Berdasarkan hasil uji pratindakan diperoleh informasi bahwa dari 21 siswa terdapat 7 siswa $(33,33 \%)$ yang mendapat nilai tuntas dan 14 siswa $(66,67 \%)$ mendapat nilai $\leq 75$ sehingga dikatakan belum tuntas. Jadi, jika dilihat dari hasil uji pratindakan dapat dikatakan bahwa kemampuan siswa kelas V SD Negeri Tegalsari No. 60 Surakarta dalam menyelesaikan soal cerita matematika dikategorikan rendah.

Permasalahan yang terjadi pada siswa kelas V SD Negeri Tegalsari No.60 Surakarta tersebut harus segera diatasi dengan melakukan perbaikan. Apabila dibiarkan dan tidak diatasi, maka dapat menimbulkan permasalahan secara berkelanjutan. Misalnya, berkurangnya kualitas pembelajaran, siswa selalu menjadi partisipan yang tidak aktif, dan kemampuan siswa dalam menyelesaikan soal cerita matematika tidak mengalami peningkatan. Padahal, pokok bahasan menyelesaikan soal cerita ini akan kembali dijumpai siswa pada tingkat pendidikan selanjutnya.

Guru perlu mengupayakan cara untuk meningkatkan kemampuan menyelesaikan soal cerita matematika siswa. Salah satu upaya yang diusulkan adalah melalui model pembelajaran yang mampu menciptakan suasana pembelajaran aktif, bermakna, dan mampu menuntun siswa berpikir kritis dalam menyelesaikan soal cerita matematika. Model pembelajaran yang dapat menjadi pilihan solusi bagi masalah rendahnya kemampuan menyelesaikan soal cerita matematika adalah model pembelajaran Logan Avenue Problem Solving (LAPS-Heuristik).

Model pembelajaran LAPS-Heuristik merupakan salah satu model pembelajaran berbasis masalah. Model pembelajaran LAPS-Heuristik merupakan rangkaian pertanyaan yang bersifat menuntun dalam menyelesaiakn masalah. Hal tersebut sesuai dengan pendapat Anggrianto, dkk yang menyatakan bahwa LAPS-Heuristik adalah model pembelajaran yang mendorong siswa dalam memecahkan masalah dengan mempertanyakan masalahnya, solusinya, dan keefektifan solusi untuk mengatasi masalah, dipublikasikan dalam Journal of Education and Practice (2016).

Model pembelajaran LAPS-Heuristik dipilih dengan alasan karena dapat menarik minat siswa terhadap mata pelajaran matematika. Salah satu kelebihan dari model pembelajaran ini adalah dapat menimbulkan keingintahuan dan motivasi. Keingintahuan dan motivasi yang tinggi dalam pembelajaran akan menimbulkan dampak positif bagi siswa. Keingintahuan dan motivasi tersebut dapat timbul karena diadakannya kerja kelompok. Melalui kegiatan secara berkelompok, siswa membangun kerjasama secara aktif dan membagi tugas yang diembannya dengan anggota kelompok agar dapat memecahkan masalah. Masalah yang diberikan juga mampu memberikan tantangan tersendiri bagi siswa. Akibatnya, timbul keantusiasan dan rasa ingin tahu dalam diri siswa. Oleh karena hal tersebut, model pembelajaran LAPSHeuristik dapat digunakan guru untuk meningkatkan kemampuan menyelesaikan soal cerita matematika siswa.

\section{METODE}

Penelitian ini dilaksanakan di SD Negeri Tegalsari No. 60 Surakarta. Penelitian ini dilaksanakan selama tujuh bulan, dimulai dari awal bulan Januari 2018 sampai dengan bulan Juli 2018. Subjek penelitian adalah siswa kelas $V$ yang berjumlah 21 siswa, terdiri dari 12 siswa laki-laki dan 9 siswa perempuan. Bentuk penelitian ini adalah Penelitian Tindakan Kelas (PTK) dengan model siklus. Tindakan penelitian dilaksanakan dalam dua siklus. Masing-masing siklus terdiri dari tiga pertemuan. Siklus I maupun siklus II terdiri dari tahap perencanaan, tahap pelaksanaan, tahap observasi, dan tahap refleksi. Pada akhir tindakan dilaksanakan tes untuk mengetahui kemampuan siswa dalam menyelesaikan soal cerita.

Data kuantitatif dalam penelitian ini didapatkan dari nilai tes kemampuan menyelesaikan soal cerita matematika, hasil observasi aktivitas siswa, dan hasil observasi kinerja guru. Data kualitataif pada penelitian ini adalah hasil wawancara, 
hasil dokumentasi yang berupa silabus, RPP, dan foto. Sumber data primer pada penelitian ini berasal dari peneliti, guru kelas, siswa kelas $\mathrm{V}$, dan peristiwa pembelajaran. Adapun sumber data sekunder berasal dari silabus semester II, RPP matematika, dan hasil dokumentasi.

Teknik pengumpulan data yang digunakan adalah observasi, wawancara, tes, dan dokumentasi. Validitas data yang digunakan yakni validitas isi, triangulasi teknik, dan triangulasi sumber. Analisis data yang digunakan berupa analisis deskriptif komparatif dan analisis interaktif Miles dan Hubberman, yang meliputi pengumpulan data, reduksi data, penyajian data, dan kesimpulan. Indikator kinerja penelitian ini adalah $80 \%$ (18 dari 21 siswa) mendapat nilai lebih besar atau sama dengan ( $\geq$ ) KKM 75 .

\section{HASIL DAN PEMBAHASAN}

Kemampuan siswa dalam menyelesaikan soal cerita matematika mengalami peningkatan setiap siklusnya. Pada kondisi awal diperoleh informasi bahwa kemampuan menyelesaikan soal cerita matematika siswa masih tergolong rendah. Hal tersebut dibuktikan dari persentase ketuntasan klasikal yang diperoleh siswa kelas $\mathrm{V}$ sebesar $33,33 \%$ atau 7 siswa mendapat nilai tuntas, sedangkan 14 siswa lainnya mendapat nilai tidak tuntas atau di bawah KKM 67 yang ditentukan sekolah. Secara keseluruhan data nilai kemampuan menyelesaikan soal cerita matematika siswa kelas $\checkmark$ pada saat pratindakan dapat dijelaskan melalui tabel 1 berikut ini:

Tabel 1. Distribusi Frekuensi Nilai Kemampuan Menyelesaikan Soal Cerita Matematika Pratindakan

\begin{tabular}{|c|c|c|c|c|c|c|}
\hline \multirow{2}{*}{ No } & \multirow{2}{*}{ Interval } & \multirow{2}{*}{$\begin{array}{l}\text { Frekuensi } \\
\text { (fi) }\end{array}$} & \multirow{2}{*}{$\begin{array}{c}\text { Nilai Tengah } \\
(\mathrm{xi})\end{array}$} & \multirow{2}{*}{ fi.xi } & \multicolumn{2}{|c|}{ Persentase (\%) } \\
\hline & & & & & Relatif & Kumulatif \\
\hline 1 & $16-26$ & 4 & 21 & 84 & 19,05 & 19,05 \\
\hline 2 & $27-37$ & 1 & 32 & 32 & 4,76 & 23,81 \\
\hline 3 & $38-48$ & 6 & 43 & 258 & 28,57 & 52,38 \\
\hline 4 & $49-59$ & 2 & 54 & 108 & 9,52 & 61,90 \\
\hline 5 & $60-70$ & 1 & 65 & 65 & 4,76 & 66,66 \\
\hline 6 & $71-81$ & 7 & 76 & 532 & 33,33 & 100 \\
\hline \multicolumn{2}{|c|}{ Jumlah } & 21 & & 1079 & 100 & \\
\hline \multicolumn{2}{|c|}{ Nilai rata-rata } & 51,09 & & & & \\
\hline \multicolumn{2}{|c|}{ Ketuntasan Klasikal } & $33,33 \%$ & & & & \\
\hline \multicolumn{2}{|c|}{ Nilai Tertinggi } & 80 & & & & \\
\hline \multicolumn{2}{|c|}{ Nilai Terendah } & 16 & & & & \\
\hline
\end{tabular}

Berdasarkan data pada tabel 1 di atas, sebagian besar siswa belum mencapai kriteria ketuntasan minimal yang sekolah tetapkan. Analisis data hasil pratindakan menunjukkan bahwa siswa mengalami kesulitan dalam menyelesaikan soal cerita matematika. Selain itu, siswa juga belum terbiasa menyelesaikan soal cerita menggunakan langkah-langkah penyelesaian yang benar. Sebagian besar siswa cenderung langsung menjawab soal tanpa mengidentifikasi hal yang diketahui, ditanyakan, dan menuliskan kesimpulan. Upaya yang diusulkan untuk mengatasi permasalahan tersebut adalah melalui penerapan model pembelajaran LAPS Heuristik pada pembelajaran menyelesaikan soal cerita.

Pelaksanaan pembelajaran menyelesaikan soal cerita matematika pada siklus I melalui model pembelajaran LAPS-Heuristik menunjukkan adanya peningkatan. Hal ini dibuktikan dengan peningkatan hasil nilai kemampuan menyelesaikan soal cerita matematika. Terjadinya peningkatan nilai ini, juga menunjukkan bahwa kemampuan siswa dalam menyelesaikan soal cerita matematika meningkat. Kondisi tersebut 
memperlihatkan bahwa model LAPS-Heuristik memberikan dampak positif terhadap kemampuan siswa dalam menyelesaikan soal cerita matematika. Melalui model LAPSHeuristik, kemampuan siswa dalam memahami masalah soal cerita, merencanakan solusi, melaksanakan penyelesaian sesuai rencana, dan menarik kesimpulan menjadi lebih baik. Selain itu, siswa juga lebih antusias, tertarik dan memiliki motivasi untuk mengikuti pembelajaran. Hal ini sesuai dengan pendapat Shoimin (2016) yang menyatakan bahwa salah satu kelebihan dari model pembelajaran LAPS-Heuristik adalah dapat menimbulkan keingintahuan dan motivasi belajar siswa. Secara keseluruhan nilai kemampuan menyelesaikan soal cerita matematika siklus I dapat dilihat pada tabel 2 berikut ini:

Tabel 2. Distribusi Frekuensi Nilai Kemampuan Menyelesaikan Soal Cerita Matematika Siklus I

\begin{tabular}{|c|c|c|c|c|c|c|}
\hline \multirow{2}{*}{ No } & \multirow{2}{*}{ Interval Nilai } & \multirow{2}{*}{$\begin{array}{l}\text { Frekuensi } \\
\text { (fi) }\end{array}$} & \multirow{2}{*}{$\begin{array}{c}\text { Nilai Tengah } \\
(x \mathrm{i})\end{array}$} & \multirow{2}{*}{ fi. $x i$} & \multicolumn{2}{|c|}{ Persentase (\%) } \\
\hline & & & & & Relatif & Kumulatif \\
\hline 1 & $42-50$ & 1 & 46 & 46 & 4,67 & 4,67 \\
\hline 2 & $51-59$ & 3 & 55 & 165 & 14,29 & 19,05 \\
\hline 3 & $60-68$ & 4 & 64 & 256 & 19,05 & 38,10 \\
\hline 4 & $69-77$ & 5 & 73 & 365 & 23,81 & 61,90 \\
\hline 5 & $78-86$ & 5 & 82 & 410 & 23,81 & 85,71 \\
\hline 6 & $87-95$ & 3 & 91 & 273 & 14,29 & 100 \\
\hline & Jumlah & 21 & & 1515 & 100 & \\
\hline & \multicolumn{2}{|c|}{ Nilai Rata-rata Kelas } & \multicolumn{2}{|l|}{73,11} & & \\
\hline & \multicolumn{2}{|c|}{ Ketuntasan Klasikal } & \multicolumn{2}{|l|}{$57,14 \%$} & & \\
\hline & \multicolumn{2}{|c|}{ Nilai Tertinggi } & \multicolumn{2}{|l|}{93,33} & & \\
\hline & \multicolumn{2}{|c|}{ Nilai Terendah } & \multicolumn{2}{|l|}{44.67} & & \\
\hline
\end{tabular}

Berdasarkan tabel 2 di atas, diperoleh informasi bahwa nilai rata-rata kelas dan ketuntasan klasikal siklus I mengalami peningkatan dibandingkan pada saat pratindakan. Akan tetapi, ketuntasan klasikal siklus I belum mencapai target yang ditentukan. Target indikator kinerja penelitian ini adalah jumlah siswa yang nilainya mencapai $\mathrm{KKM} \geq 75$ sebanyak $80 \%$. Artinya, sebanyak 17 siswa dari jumlah seluruh siswa kelas $V$ yaitu 21 siswa mendapat nilai $\geq 75$. Pada siklus I sebagian besar siswa sudah mampu menyelesaikan soal cerita, namun masih terdapat beberapa siswa yang mengalami kesulitan.

Kesulitan yang dialami siswa antara lain: (1) siswa belum lengkap menuliskan langkah-langkah menyelesaikan soal cerita matematika, (2) siswa kurang teliti dalam melaksanakan tahapan pemeriksaan kembali terhadap hasil yang diperoleh, (3) ada sebagian siswa yang belum selesai mengerjakan soal evaluasi sesuai waktu yang ditentukan guru. Hal tersebut ditunjukkan dari ketuntasan klasikal yang diperoleh sebesar 57,14\% atau 12 siswa mencapai KKM. Artinya, masih terdapat 9 siswa yang belum mendapat nilai tuntas. Oleh karena itu, peneliti melakukan perbaikan dan melanjutkan tindakan ke siklus II.

Pada siklus II, nilai kemampuan menyelesaikan soal cerita matematika siswa mengalami peningkatan kembali. Peningkatan tersebut dapat di lihat dari nilai rata-rata kelas yang diperoleh. Selain nilai rata-rata kelas, bisa juga dilihat dari ketuntasan klasikal yang diperoleh. Peningkatan yang terjadi tersebut tidak terlepas dari upaya perbaikan yang sudah dilakukan. Upaya yang dilakukan antara lain: (1) guru lebih membimbing dan mengingatkan kembali kepada siswa agar di dalam menyelesaikan soal cerita menggunakan langkah-langkah yang benar dan lengkap, (2) guru senantiasa mengingatkan siswa agar memeriksa pekerjaannya kembali sebelum dikumpulkan, (3) guru membimbing siswa untuk mengerjakan soal tepat waktu. 
Peningkatan yang terjadi tersebut, juga semakin membuktikan bahwa model pembelajaran LAPS-Heuristik mampu meningkatkan kemampuan siswa dalam menyelesaikan soal cerita matematika. Secara keseluruhan, hasil penilaian kemampuan menyelesaikan soal cerita matematika siklus II dapat dilihat pada tabel 3 berikut ini:

Tabel 3. Distribusi Frekuensi Nilai Kemampuan Menyelesaikan Soal Cerita Matematika Siklus II

\begin{tabular}{|c|c|c|c|c|c|c|}
\hline \multirow{2}{*}{ No } & \multirow{2}{*}{ Interval nilai } & \multirow{2}{*}{$\begin{array}{l}\text { Frekuensi } \\
\qquad(f i)\end{array}$} & \multirow{2}{*}{$\begin{array}{c}\text { Nilai Tengah } \\
(x I)\end{array}$} & \multirow{2}{*}{ fi. $x i$} & \multicolumn{2}{|c|}{ Persentase (\%) } \\
\hline & & & & & Relatif & Kumulatif \\
\hline 1 & $65-70$ & 2 & 67,5 & 135 & 9,52 & 9,52 \\
\hline 2 & $71-76$ & 3 & 73,5 & 220,5 & 14,29 & 23,81 \\
\hline 3 & $77-82$ & 3 & 79,5 & 238,5 & 14,29 & 38,10 \\
\hline 4 & $83-88$ & 3 & 85,5 & 256,5 & 14,29 & 52.38 \\
\hline 5 & $89-94$ & 5 & 91,5 & 457,5 & 23,81 & 76,19 \\
\hline 6 & $95-100$ & 5 & 97,5 & 487,5 & 23,81 & 100 \\
\hline \multirow{2}{*}{\multicolumn{3}{|c|}{$\begin{array}{ll}\text { Jumlah } & 21 \\
\text { Nilai Rata-rata Kelas } & \end{array}$}} & & 1704 & 100 & \\
\hline & & & 86,35 & & & \\
\hline \multicolumn{3}{|c|}{ Ketuntasan Klasikal } & $85,71 \%$ & & & \\
\hline \multicolumn{3}{|c|}{ Nilai Tertinggi } & 100 & & & \\
\hline \multicolumn{3}{|c|}{ Nilai Terendah } & 65 & & & \\
\hline
\end{tabular}

Berdasarkan data tabel 3 tersebut, dapat diperoleh informasi bahwa sebagian besar siswa nilainya sudah berada di atas KKM. Hal ini dapat dilihat dari nilai rata-rata dan ketuntasan klasikal yang diperoleh. Nilai rata-rata siklus II sebesar 86,35 dan ketuntasan klasikal sebesar $85,71 \%$. Artinya terdapat 18 siswa yang mendapat nilai tuntas, tetapi masih ada 3 siswa yang mendapat nilai tidak tuntas atau di bawah KKM. Hal tersebut dikarenakan ketidaktelitian siswa dalam menuliskan jawaban yang dimaksudkan dalam soal cerita.

Ketuntasan klasikal yang diperoleh pada siklus II ini sudah melampaui indikator kinerja yang ditetapkan (sebesar $80 \%$ ). Hal ini menunjukkan bahwa siswa sudah mampu menyelesaikan soal cerita matematika. Indikator tersebut dapat tercapai karena guru dan siswa dapat melaksanakan pembelajaran dengan baik, sesuai rencana perbaikan siklus I.

Pencapaian indikator tersebut menunjukkan bahwa model pembelajaran LAPSHeuristik dapat meningkatkan kemampuan menyelesaikan soal cerita matematika siswa. Melalui model pembelajaran LAPS-Heuristik, keterlibatan siswa lebih ditekankan secara utuh untuk menemukan prosedur penyelesaian soal cerita matematika. Selain itu, siswa juga mampu memperdalam kemampuannya untuk memahami masalah, menyusun rencana, melaksanakan solusi, maupun melakukan pemeriksaan kembali guna menyelesaikan masalah. Hal tersebut sesuai dengan pendapat Ngalimun (2014) yang menyatakan bahwa sintaks dari model LAPS-Heuristik adalah pemahaman masalah, rencana, solusi, dan pengecekan.

Lebih lanjut, mengenai langkah-langkah model pembelajaran LAPS-Heuristik, Vilianti et al (2018) dalam jurnal Description of The Ability of Social Arithedical Stories by Study Problem by Students. The International Journal of Active Learning, ijal 3 (11), menyataka bahwa: "Stage Polya consists of understanding the problem, making plans, implementing plans and re-checking". Maksud dari pernyataan Vilianti, dkk (2018) yaitu bahwa tahap polya terdiri dari pemahaman masalah, membuat rencana, melaksanakan rencana dan pengecekan ulang.

Penerapan model pembelajaran LAPS-Heuristik dalam pembelajaran menyelesaikan soal cerita terbukti dapat memberikan dampak positif terhadap siswa. 
Siswa menjadi termotivasi untuk aktif dan antusias mengikuti pembelajaran.Siswa bertanya jawab dengan guru maupun temannya untuk menyelesaikan permasalahan dalam soal cerita.

Hal ini dikarenakan model pembelajaran LAPS-Heuristik mampu memotivasi siswa untuk melatih kemampuannya menyelesaikan masalah. Masalah yang disajikan dalam penelitian ini berbentuk soal cerita matematika. Hal tersebut senada dengan pendapat Purba dan Sirait (2017) yang menyatakan bahwa model pembelajaran LAPS-Heuristik mampu memotivasi siswa dan menumbuhkan keingintahuan yang tinggi.

Selain itu, rangkaian pertanyaan yang terdapat dalam konsep heuristik juga membantu mempermudah siswa dalam menyelesaikan masalah. Nurdin (Shoimin, 2016: 96) mengatakan bahwa heuristic adalah suatu penuntun berupa pertanyaan yang diperlukan untuk menyelesaikan suatu masalah. Menurut Sukirman (2016) heuristik merupakan suatu arahan atau tuntunan yang sistematis dalam memecahkan masalah matematika. Lebih lanjut Winarni dan Harmini (2011) menjelaskan bahwa heuristik merupakan pendekatan pemecahan masalah yang dapat mendorong siswa bekerja secara aktif, kreatif, dan inovatif sesuai dengan kemampuan sendiri. Heuristic berfungsi mengarahkan pemecahan masalah siswa untuk menemukan solusi dari masalah yang diberikan.

Berdasarkan penjelasan di atas, maka dapat disimpulkan bahwa model pembelajaran LAPS-Heuristik merupakan model pembelajaran yang baik diterapkan dalam pembelajaran menyelesaikan soal cerita matematika. Model pembelajaran ini memberikan tantangan tersendiri bagi siswa untuk memecahkan masalah yang ada dalam soal. Selain itu, penerapan model ini juga membantu meningkatkan kemampuan siswa dalam menyelesaikan soal cerita.

\section{SIMPULAN}

Berdasarkan hasil penelitian dan pembahasan yang dilaksanakan dalam dua siklus, menunjukkan bahwa model pembelajaran LAPS-Heuristik dapat meningkatkan kemampuan menyelesaikan soal cerita matematika siswa kelas V SD Negeri Tegalsari No. 60 Surakarta tahun ajaran 2017/2018. Pembelajaran menyelesaikan soal cerita matematika berlangsung sesuai dengan langkah-langkah model pembelajaran LAPSHeuristik yang dirancang. Hasil yang diperoleh yaitu, sebanyak 18 siswa berhasil mencapai nilai $\mathrm{KKM} \geq 75$. Kondisi tersebut memberikan arti bahwa sebanyak 18 siswa $(85,57 \%)$ mampu atau memiliki kemampuan dalam menyelesaikan soal cerita. Dengan demikian, indikator kinerja penelitian ini dinyatakan sudah tercapai.

\section{DAFTAR PUSTAKA}

Anggrianto, D., Churiyah, M., \& Arief, M. (2016). Improving Critical Thinking Skills Using Learning Model Logan Avenue Problem Solving (LAPS)-Heuristic. Journal of Education and Practice, 7 (9), 2222-1735.

Laily, I. F. (2014). Hubungan Kemampuan Membaca Pemahaman dengan Kemampuan Memahami Soal Cerita Matematika Sekolah Dasar. Jurnal EduMa, 3 (1), 2086-3918.

Ngalimun. (2014). Strategi dan Model Pembelajaran. Yogyakarta: Aswaja Pressindo.

Purba, O. N. \& Sirait, S. (2017). Peningkatan Kemampuan Pemecahan Masalah pada Materi Trigonometri dengan Model LAPS-Heuristik pada Kelas X SMA. Prosiding Seminar Nasional Multidisiplin IImu, FKIP UNA.

Shadiq, Fadjar. (2014). Pembelajaran Matematika; cara Meningkatkan Kemampuan Berpikir Siswa. Yogyakarta: Graha IImu. 
Shoimin, A. (2016). 68 Model Pembelajaran Inovatif dalam Kurikulum 2013. Yogyakarta: Ar-Ruzz Media.

Sukirman. (2016). Matematika untuk Guru dan Calon Guru Pendidikan Dasar. Yogyakarta: UNY Press.

Sunarto \& Hartono. (2008). Perkembangan Peserta Didik. Jakarta: PT Rineka Cipta.

Vilianti, Y. C., Pratama, F. Y. \& Mampouw, H. L. (2018). Description of The Ability of Social Arithedical Stories by Study Problems by Students VIII SMP Reviewed from The Polya Stage. International Journal of Active Learning, 3 (1), 2528$505 X$.

Winarni dan Harmini. (2011). Matematika untuk PGSD. Bandung: PT Remaja Rosdakarya. 